\title{
EVALUATION OF "BELAJAR BAHASA MANDARIN PINTAR DAN CERDAS DENGAN PANDUAN 3 BAHASA UNTUK KELAS 1 SD"
}

\author{
Sudono Noto Pradono \\ NSC Surabaya Polytechnic \\ Email: sudono32@yahoo.com
}

\begin{abstract}
Evaluation of "Belajar Bahasa Mandarin Pintar dan Cerdas dengan Panduan 3 Bahasa untuk Kelas 1 SD" which is used for grade one elementary students is intended to know whether the textbook can be adopted or adapted by identifying the strengths and weaknesses. The result of the evaluation is that the textbook of "Belajar Bahasa Mandarin Pintar dan Cerdas dengan Panduan 3 Bahasa untuk Kelas 1 SD" cannot be adopted to be used for grade one elementary students, but it can be adapted.
\end{abstract}

Key words: evaluation, textbook, activities.

\section{INTRODUCTION}

Since Indonesian government has allowed Mandarin language to be taught in schools, there are many Mandarin textbooks which are available in the bookstores. Therefore, selecting an appropriate Mandarin textbook to be taught to students is very important. Evaluating Mandarin textbook can help in selecting an appropriate Mandarin textbook, so the chosen Mandarin textbook can be decided whether to be adopted or adapted.

The data of the textbook that the writer evaluated are as follows: the title: "Belajar Bahasa Mandarin Pintar dan Cerdas dengan Panduan 3 Bahasa untuk Kelas 1 SD", written by Yi Ying, Damalia J, Wang Qiang, editor: Benedicta Rini W, published by ANDI OFFSET, Yogyakarta, 2013, ISBN 978-979-29-3350-5, 48 pages, and the price is Rp. 47.000 .

The purpose of the evaluation of "Belajar Bahasa Mandarin Pintar dan Cerdas dengan Panduan 3 Bahasa untuk Kelas 1 SD" is to know whether this book can be adopted or adapted. Cunningsworth (1995: 14) states that the intention to adopt new textbooks is a major and frequent reason for evaluation. Another reason is to identify particular strength and weaknesses in textbooks already in use, so that optimum use can be made of their strong points, whilst their weaker areas can be strengthened through adaptation or by substituting material from other books.

\section{LITERATURE REVIEW}

Richards (2001 : 254-255) argues that the use of commercial textbooks in teaching has both advantages and disadvantages. The advantages are: 1) they provide structure and a syllabus for a program, 2) they help standardize instruction, 3) they maintain quality, 4) they provide a variety of learning resources, 5) they are efficient, 6) they can provide effective language models and input, 7) they can train teachers, and 8) they are visually appealing. On the other hand, the disadvantages are: 1) they may contain inauthentic language, 2) they may distort content, 3) they may not reflect students' needs, 4) they can deskill teachers, and 5) they are expensive. Since there are the advantages and disadvantages of the commercial textbooks, therefore, evaluation is needed.

Cunningsworth (1995:15-16) proposes four guidelines for evaluating textbooks. They are as follows: 1) textbooks should correspond to learners' need. They should match the aims and objectives of the language learning program, 2) textbooks should reflect the uses (present or future) which learners will make of the language. The chosen textbooks should help to equip 
students to use language effectively for their own purposes, 3) textbooks should take account of students' needs as learners and should facilitate their learning processes, without dogmatically imposing a rigid "method", 4) textbooks should have a clear role as a support for learning. Like teachers, they mediate between the target language and the learner.

After evaluating textbooks, teachers can decide whether they want to adopt or to adapt the textbooks. However, Richards (2001 : 260) argues that commercial textbooks can seldom be used without some form of adaptation to make them more suitable for the particular context in which they will be used. This adaptation may take a variety of forms, they are: 1) modifying content, 2) adding or deleting content, 3 ) reorganizing content, 4) addressing omissions, 5) modifying tasks, and 6) extending tasks.

\section{METHODOLOGY}

The contents of "Belajar Bahasa Mandarin Pintar dan Cerdas dengan Panduan 3 Bahasa untuk Kelas 1 SD" consist of 5 lessons. The writer evaluated the textbook based on the checklist for evaluation and selection proposed by Cunningsworth (1995 : 3-4). The checklist for evaluation and selection consisted of 1) aim and approach, 2) design and organization, 3) language content, 4) skills, 5) topic, 6) methodology, 7) teacher's book, and 8) practical consideration.

\section{FINDINGS and DISCUSSION}

Based on the checklist for evaluation and selection proposed by Cunningsworth (1995: $3-4)$, the findings and discussion are elaborated as follows:

\section{Aim and approach}

The aim of "Belajar Bahasa Mandarin Pintar dan Cerdas dengan Panduan 3 Bahasa untuk Kelas 1 SD" is not available in the textbook. However from the titles of 5 lessons, the writer could know the aim of the textbook. The titles of 5 lessons are as follows: lesson 1: Hello!; lesson 2: My family; lesson 3: How are you?; lesson 4:
Counting; lesson 5: What time is it? It seems that the aim of the textbook is that the students are able to do short conversation in topics for everyday.

It also seems that "Belajar Bahasa Mandarin Pintar dan Cerdas dengan Panduan 3 Bahasa untuk Kelas 1 SD" applies behaviorist approach. Paul (2003 : 3) states that the behaviorist approach focuses on the reinforcement of behavior through repetition and rewards. In the classroom, this has tended to imply that students should be regarded as blank slates until they are taught by more knowledgeable adults. A lesson influenced by the behaviorist approach generally contains some or all of the following five elements: 1) the teacher is clearly in control both of the students' behavior and of the learning process, while the students respond to the teacher's directions and stimuli, and they tend to passively follow the teacher, 2) the teacher has a clear lesson plan and step-by-step syllabus, 3) language patterns are repeated through drills and choral repetition until the students become automatic, 4) it is considered essential for the students to succeed as much as possible, therefore, the students are protected from making errors, 5) success is strengthened by praise and rewards. For example: on page 9, lesson 2: my family, the vocabularies of family members are introduced like 爷爷 (grandfather), 奶奶 (grandmother), 爸爸(father), 妈妈 (mother), 哥哥(older brother), 姐姐(older sister), 弟弟 (younger brother), and 妹妹 (younger sister). Simple pattern of sentences are also introduced like 这是我爸爸 (this is my father), 这是我妈妈 (this is my mother). On page 10, the students are asked to read aloud. Then on page 11, the students are asked to do substitution drill.

Richards \& Rodgers (2001: 66) state that Chomsky proposed that behaviorist approach was subject to the same laws of stimulus and response, reinforcement and association. Chomsky argued that such a learning theory could not possibly serve as a model of how students learn language, since much of 
human language use is not imitated behavior but is created anew from underlying knowledge of abstract rules. Sentences are not learned by imitation and repetition but "generated" from the students' underlying "competence." However, Paul (2003 : 37) says that teachers consider repetition drills as an essential part of a lesson. They believe that students need to repeat the same words and patterns over and over again, and in most cases this is true.

\section{Design and organization}

The total course package of "Belajar Bahasa Mandarin Pintar dan Cerdas dengan Panduan 3 Bahasa untuk Kelas 1 SD" is student's book only. Workbook, teacher's book, class CD or cassette, picture card, video, and video book are not available. Pinter (2006 : 14) says that it is important for teachers to take into account that all students have stronger and weaker aspects of their multiple intelligences and preferred learning styles. Some of the early preferences and styles might change with time but there will always be a variety of learners in every class. Therefore teachers need to incorporate a variety of activities into second and foreign language classrooms to ensure that everybody's preferences are catered for at least some of the time. Since the CD or cassette of "Belajar Bahasa Mandarin Pintar dan Cerdas dengan Panduan 3 Bahasa untuk Kelas 1 SD" is not available, the teacher should make a recording to accommodate for the students with an auditory learning style. Then, the picture cards are also not available, therefore, the teacher should make picture cards to accommodate students with a visual learning style. Finally, the teacher should make movement activities to accommodate students with a kinesthetic learning style.

The syllabus of "Belajar Bahasa Mandarin Pintar dan Cerdas dengan Panduan 3 Bahasa untuk Kelas 1 SD" is as follows: : lesson 1: Hello!; lesson 2: My family; lesson 3: How are you?; lesson 4: Counting; lesson 5: What time is it?. It seems that "Belajar Bahasa Mandarin Pintar dan Cerdas dengan Panduan 3 Bahasa untuk Kelas 1 SD" applies topical or content-based syllabus. According to Richards (2001 : 157), topical or contentbased syllabus is organized around themes, topics, or other units of content. Cunningsworth (1995: 58) also states that topic can be of great value in keeping students' interest and maintaining or increasing their motivation. Additionally, it provides a focus for the language input contained in the course and helps to create a sense of coherence within individual units.

In this textbook, the sequence of the content is not in the correct order. It should be from the easiest and simplest one to the most difficult and complicated one. For example:

In lesson 1, the students should learn to write the following characters:

我 (I) which has 7 strokes.

你 ( you ) which has 7 strokes.

他 ( he ) which has 5 strokes.

In lesson 4, the students should learn to write the following characters:

- ( one ) which has 1 stroke.

二 ( two ) which has 2 strokes.

三 ( three ) which has 3 strokes.

Cunningsworth (1995: 59) states that sequencing refers to the order in which new items are taught, how the components fit with one another and how the range of language taught develops as learners progress through the course. Implicit in sequencing is the concept of progression, with the expectation that there will be a principled development from a beginning point to an end point.

There is adequate recycling in the textbook. For example: the word 我 ( I ) appears in lesson 1. This word 我 ( I ) reappears again in lesson 2 and 3. Cameron (2001: 84) states that vocabulary needs to be met and recycled at intervals, in different activities, with new knowledge and new connections developed each time the same words are met again. Nation (1990, in Cameron, 2001: 84) argues that a new word requires to be met at least five or six times in a textbook unit before it has any chance of being learnt. The emphasis is the need for words to reappear, not just in a unit, but 
across units or chapters, and across levels and years. For students who start language learning young, this is very important.

\section{Language Content}

Each lesson contains new target language. For example: the target language of lesson 2 is 爷爷 (grandfather), 奶奶 (grandmother), 爸 爸 (father), 妈 妈 (mother), 哥 哥 (older brother), 姐姐(older sister), 弟弟 (younger brother), and 妹妹 (younger sister). The number of new target language in each lesson that the grade one elementary students have to learn are quite reasonable. Cameron (2001 : 81) argues that students studying a foreign language require very concrete vocabulary that connects with objects they can handle or see, while older students can master words and topics that are more abstract and remote from their experience.

Songs are available in the textbook. For example: in lesson 4, there is a song entitled 我的朋友在哪里? (where are my friends?). Unfortunately, the melody is not available, therefore, if inexperienced teachers do not recognize the song, they will get difficulty in teaching the song to their students. Paul (2003 : 58) argues that songs can add feeling and rhythm to language practice that might otherwise be flat, help students remember things more easily, and draw students more deeply into a lesson. Most students love songs, and songs and chants are one aspect of the language class that most students study with genuine feeling and take home with them. They keep songs and chants in their heads, sing them after class, hum them on the way home, and sing them at home. Therefore, the existence of songs and chants is very important for the grade one primary students.

The textbook offers L1 translation. According to Krashen (1989 : 75), the first language can be used improperly as well, in a way that discourages comprehensible input. This occurs when concurrent translation is used, a technique in which the teacher speaks a little in one language, then translates what was said into the other language. When this happens, students quite naturally listen to the message in their own language and pay no attention to the target language input. In concurrent translation, the teacher does not have to try to make the target language input comprehensible by using extra linguistic support (realia, gesture) or paraphrase because a translation is available.

\section{Skills}

Listening activities are not available in the textbook. Therefore, the teacher should add listening activities. Paul (2003: 72) suggests that when students listen to a tape first, they tend to guess and interact less, so it is usually best to have some kind of practice before listening. This can include using some of the language on the tape interactively, playing a game that includes some of the new words or patterns on the tape, or asking the students to do a puzzle while listening to the tape. For example, the students can have a series of pictures that illustrate what is on the tape. These pictures are mixed up, and the children put them in the correct order when they listen. In this kind of activity, they are thinking and solving a puzzle, not just listening to the tape passively.

There are short conversations in the textbook. For example: lesson 1 page 5, there is a short dialog between 大伟(David) and 玛 丽 (Mary). Scott and Ytreberg (2000 : 39) state that working with dialogs is a useful way to bridge the gap between guided practice and freer activities. Controlled dialogs can easily develop into freer work when the students are ready for it. Putting students into pairs for doing the dialogs is a simple way of organizing even large classes.

Reading activities are available in the textbook. For example: lesson 2 page10, students will learn to read 爷爷 (grandfather), 奶奶 (grandmother), 爸爸 (father), 妈妈 (mother), 哥哥 (older brother), 姐姐 (older sister), 弟弟 (younger brother), and 妹妹 (younger sister). Scott and Ytreberg (2000 : 50) argue that one of the reading approaches is "look and say". This approach is based on words and phrases, and makes a lot of use of flashcards. It is usual to start by teaching everyday words which are already familiar to 
the children. The teacher shows the students the word and says it while pointing to the object. The students repeat the word. This happens several times with each word. Therefore, this approach encourages recognition of a range of words and phrases before reading a text. Since the flashcards are not available, the teachers who use this textbook should make flashcards by themselves.

Writing activities are available in the textbook. For example: lesson 4 page 34 and 35 , the students will learn to copy the character of - (one) until 十 (ten).

According to Scott and Ytreberg (2000 : 70), copying is a fairly obvious starting point for writing. It is an activity which gives the teacher the chance to reinforce language that has been presented orally or through reading. It is a good idea to ask students to read aloud quietly to themselves when they are copying the words because this helps them to see the connection between the written and the spoken word.

\section{Topic}

The topics in the textbook are introduction, family, greeting, counting, and timing. The topics are suitable for the grade one elementary students. Cunningsworth (1995 : 86) states that although language textbooks are primarily a means for facilitating language learning, they cannot simply do that and no more, because language is used in real situations for real purposes. A study of a language solely as an abstract system would not equip students to use it in the real world. As a consequence, textbooks must and do represent language as it is actually used and therefore they contain subject matter and deal with topics of various kinds. Unfortunately, the topics in the textbook are not sufficient for one year learning because there are only five topics. Therefore, the teachers who use this textbook should add more interesting topics which are suitable for grade one elementary students.

\section{Methodology}

It seems that "Belajar Bahasa Mandarin Pintar dan Cerdas dengan Panduan 3 Bahasa untuk Kelas 1 SD" uses the Audio-Lingual Method based on behaviorist approach because some of the principles of the AudioLingual Method can be seen in the textbook. They are elaborated as follows:

a) The goal of using Audio-Lingual Method is that students are able to use the target language communicatively. In order to do this, teachers believe students need to over learn the target language, to learn to use it automatically without stopping to think. Their students achieve this by forming new habits in the target language and overcoming the old habits of their native language (Larsen-Freeman, 2000 : 45). For example: lesson 1, although the objectives of lesson 1 are not stated, the objectives can be known from its content. One of objectives is that students are able to do a short conversation because there is a short conversation on page 5 .

b) The teacher directs and controls the language behavior of the students. The teacher is also responsible for providing a good model for imitation. On the other hand, the students are imitators of the teacher's model or the tapes that the teacher supplies of model speakers, they follow the teacher's directions and respond as accurately and as rapidly as possible (Larsen-Freeman, 2000 : 45) For example: lesson 2 page 10 in reading aloud. The teacher should give the model how to read 爷 爷 (grandfather), 奶奶(grandmother), 爸爸 (father), 妈 妈 (mother), 哥 哥 (older brother), 姐姐 (older sister), 弟弟 (younger brother), and 妹妹 (younger sister). The students are imitators of their teacher.

c) The emphasis in the Audio-Lingual Method is on the everyday speech. The level of complexity of the speech is graded, so that beginning students are presented with only simple patterns 
(Larsen-Freeman, 2000 : 46). For example: lesson 1 is about introduction between 大伟(David) and 玛丽 (Mary).

Although this textbook mainly uses teaching-centered which means that the teacher controls and directs the students, there is still a room for the students to do learning-centered. For example: lesson 2 on page 13 the students can stick the photos of their family, and then they can introduce their family member to the teacher and classmates. It means that the textbook tries to make a balance between teaching-centered and learning-centered.

\section{Teacher's book}

The teacher's book is not available, therefore, the teachers who use this textbook should be able to manage creatively, so that the teaching learning activities become interesting for grade one elementary students.

\section{Practical consideration}

The textbook of "Belajar Bahasa Mandarin Pintar dan Cerdas dengan Panduan 3 Bahasa untuk Kelas 1 SD" is quite strong and long-lasting. Besides that, its appearance is very colorful and attractive. However, the price of the textbook is rather expensive. It will be a problem for students in the remote area of Indonesia.

\section{CONCLUSION}

The result of the evaluation is that the textbook of "Belajar Bahasa Mandarin Pintar dan Cerdas dengan Panduan 3 Bahasa untuk Kelas 1 SD" cannot be adopted to use for grade one elementary students, but it can be adapted. The teachers should be creative in adding some teaching materials, so that the teaching learning activities become more interesting.

\section{REFERENCES}

Cameron, L. 2001. Teaching Languages to Young Learners. Cambridge. Cambridge University Press.

Cunningsworth, A. 1995. Choosing Your Coursebook. Oxford. Macmillan Education.

Krashen, S. 1989. Language Acquisition and Language Education. Hertfordshire. Prentice Hall International.

Larsen-Freeman, D. 2000. Techniques and Principles in Language Teaching. Oxford. Oxford University Press.

Paul, D. 2003. Teaching English to Children in Asia. Hong Kong. Longman Asia ELT.

Pinter, A. 2006. Teaching Young Language Learners. Oxford. Oxford University Press.

Richards, J. C. 2001. Curriculum Development in Language Teaching. Cambridge. Cambridge University Press.

Richards, J. C. \& Rodgers, T. S. 2001. Approaches and Methods in Language Teaching. Cambridge. Cambridge University Press.

Scott, W. A. and Ytreberg, L. H. 2000. Teaching English to Children. New York.Longman.

Yi, Y., Damalia J, and Wang, Q. 2013. Belajar Bahasa Mandarin Pintar dan Cerdas dengan Panduan 3 Bahasa untuk Kelas 1 SD. Yogyakarta. ANDI OFFSET. 